\title{
Role of procalcitonin as an early market in diagnosis and follow up of surgical site infection in Al Azhar University Hospital - New Damietta, Egypt
}

\author{
M Abdelnasser ${ }^{1 *}$, M Gohar ${ }^{1}$, M Saleh${ }^{1}$, M Abdelhamid ${ }^{1}$, M Balboula $^{2}$ \\ From 3rd International Conference on Prevention and Infection Control (ICPIC 2015) \\ Geneva, Switzerland. 16-19 June 2015
}

\begin{abstract}
Introduction
Identifying patients with bacterial infection and sepsis is a major challenge in emergency departments and critical care units. Procalcitonin (PCT), the prohormone of calcitonin, was described as innovative parameter in early diagnosis of infection.
\end{abstract}

\section{Objectives}

This work was carried out to evaluate the role of PCT as an early marker in diagnosis and follow up of patients with surgical site infection.

\section{Methods}

The study was conducted on 50 patients admitted in the surgical departments of New Damietta, University Hospital, in the period between September 2012 and September 2013. Blood, urine and/or pus cultures were done. White blood cell (WBC) counts were determined using the automated hematology analyzer. Serum Creactive protein (CRP) level was measured by the semiquantitative latex agglutination test. Serum PCT concentrations were determined using the enzyme linked immunosorbent assay (ELISA).

\section{Results}

Postoperative infections were found in 29 patients $(58 \%)$ with SSI in $11(22 \%)$, urinary tract infection (UTI) in 5 (10\%), blood stream infection (BSI) in 4 (8\%), SSI and BSI in $7(14 \%)$ and SSI and UTI in $2(4 \%)$ of these patients. Staphylococcus aureus \& coagulase negativeStaphylococci were the most frequently isolated pathogens, followed by Escherichia coli, Pseudomonas aeruginosa,

${ }^{1}$ Microbiology \& Immunology, Faculty of Medicine, Al-Azhar University, Cairo, Egypt

Full list of author information is available at the end of the article
Proteus mirabilis, Candida albicans, Salmonella Paratyphi $\mathrm{B}$ and Klebsiella pneumoniae. Most of the isolated organisms were sensitive to Imipenem. Among the infected group, median serum levels of PCT and Temperature were higher $(\mathrm{P}<0.001)$ in the early phase (one day after operation, $1.20 \mathrm{ng} / \mathrm{m}, 36.5^{\circ} \mathrm{C}$ ) more than preoperative phase $\left(0.11 \mathrm{ng} / \mathrm{ml}, 37.7^{\circ} \mathrm{C}\right)$ and the late phase ( 5 days after operation: $0.46 \mathrm{ng} / \mathrm{ml}, 37.5^{\circ} \mathrm{C}$ ). Median serum levels of CRP and WBC were increased gradually $(\mathrm{P}<0.001)$ from the base line to the late phase $(5.0 \mathrm{mg} / \mathrm{l}$, $12.0 \mathrm{mg} / \mathrm{l}, 48.0 \mathrm{mg} / \mathrm{l}$ for CRP and $5.3 \mathrm{~K} / \mathrm{uL}, 10.1 \mathrm{~K} / \mathrm{uL}$, $11.2 \mathrm{~K} / \mathrm{uL}$ for $\mathrm{WBC}$, respectively).

\section{Conclusion}

These data indicate that PCT is greatly helpful to distinguish an infection from an inflammation. Moreover, it plays a very important prognostic role in the early detection of patients at risk of infection in the post-operative period.

\section{Disclosure of interest}

M. Abdelnasser Employee of: Al-Azhar University, M. Gohar Employee of: Al-Azhar University, M. Saleh Employee of: Al-Azhar University, M. Abdelhamid Employee of: Al-Azhar University, M. Balboula Employee of: Al-Azhar University.

\section{Authors' details}

${ }^{1}$ Microbiology \& Immunology, Faculty of Medicine, Al-Azhar University, Cairo, Egypt. ${ }^{2}$ Surgery, Faculty of Medicine, Al-Azhar University, Cairo, Egypt.

Published: 16 June 2015

doi:10.1186/2047-2994-4-S1-P85

Cite this article as: Abdelnasser et al:: Role of procalcitonin as an early market in diagnosis and follow up of surgical site infection in Al Azhar University Hospital - New Damietta, Egypt. Antimicrobial Resistance and Infection Control 2015 4(Suppl 1):P85. 